\title{
PENERAPAN MODEL PEMBELAJARAN TAI (TEAM ASSISTED INDIVIDUALIZATION) BERBANTUAN BUKU SAKU UNTUK MENINGKATKAN MINAT DAN PRESTASI BELAJAR SISWA PADA MATERI STOIKIOMETRI KELAS X IPA 6 SMA NEGERI 2 KARANGANYAR TAHUN PELAJARAN 2015/2016
}

\author{
Primadi Gayuh Laksono Putro, Widiastuti Agustina E S*, dan Bakti Mulyani
}

Program Studi Pendidikan Kimia, FKIP, Universitas Sebelas Maret, Surakarta, Indonesia

*Keperluan Korespondensi, telp: 081280660500, email: widiastuti_aes@staff.uns.ac.id

\begin{abstract}
ABSTRAK
Tujuan penelitian ini adalah untuk meningkatkan minat prestasi belajar siswa kelas X IPA 6 SMA Negeri 2 Karanganyar pada materi Stoikiometri melalui penerapan model pembelajaran TAI (Team Assisted Individualization) berbantuan buku saku. Penelitian ini merupakan Penelitian Tindakan Kelas yang dilaksanakan dalam dua siklus, dengan tiap siklus terdiri atas perencanaan tindakan, pelaksanaan tindakan, observasi dan refleksi. Subjek penelitian adalah siswa kelas $X$ IPA 6 SMA Negeri 2 Karanganyar yang berjumlah 29 siswa. Teknik pengumpulan data adalah dengan tes dan non tes (observasi, wawancara dan angket). Analisis data menggunakan teknik analisis deskriptif kualitatif dengan triangulasi data. Berdasarkan hasil penelitian dapat disimpulkan bahwa penerapan model pembelajaran TAI (Team Assisted Individualization) berbantuan buku saku dapat meningkatkan minat dan prestasi belajarsiswa pada materi stoikiometri kelas X IPA 6. Pada siklus I, persentase ketercapaian minat belajar siswa sebesar $100 \%$ sehingga hanya dilakukan pada siklus I. Peningkatan prestasi belajar dilihat dari aspek pengetahuan pada siklus I sebesar $41,38 \%$ dan meningkat pada siklus II menjadi $72,41 \%$, dari aspek sikap hanya dilakukan pada siklus I, persentase ketercapaian pada siklus I sebesar $100 \%$. Sedangkan untuk prestasi belajar aspek keterampilan hanya dilakukan pada siklus I dan memberikan hasil ketercapaian sebesar $100 \%$.
\end{abstract}

Kata kunci: team assisted individualization, buku saku, minat, prestasi belajar, stoikiometri

\section{PENDAHULUAN}

Peningkatan kualitas pendidikan di Indonesia terus dilakukan oleh pemerintah. Mulai dari pembaharuan kurikulum, perbaikan sarana pendidikan, pengembangan dan pengadaan materi ajar, pemerataan pendidikan, serta peningkatan kualitas tenaga pendidik. Salah satu upaya pembaharuan kurikulum adalah terbitnya kurikulum 2013 sebagai penyempurna kurikulum sebelumya yaitu kurikulum tingkat satuan pendidikan (2006-2013). Kurikulum 2013 dikembangkan secara komprehensif, integratif, dinamis, akomodatif, dan antisipatif terhadap tantangan pada masa yang akan datang [1]. Kurikulum 2013 didesain berdasarkan pada budaya dan karakter bangsa, berbasis peradaban, dan berbasis kompetensi.

Kimia dalam kurikulum 2013 merupa kan salah satu mata pelajaran kelompok peminatan Matematika dan IImu Alam. Pembelajaran kimia merupakan salah satu cabang IImu Pengetahuan Alam (IPA) yang terkesan sulit.Salah satu faktor penyebab pembelajaran kimia terkesan sulit adalah bahwa beberapa konsep dalam kimia bersifat abstrak serta dikarenakan kimia memiliki perbendaharaan kata yang khusus, dimana mempelajari kimia seperti mempelajari bahasa yang baru [2]. Selain hal tersebut, dalam pembelajaran kimia terdapat pemahaman konsep, perhitungan dan hafalan. Sehingga diperlukan pemilihan model dan metode pem- 
belajaran yang tepat, sesuai dengan karakteristik materi agar pembelajaran kimia dapat tersampaikan dengan baik.

Keberhasilan proses belajar mengajar di tunjang oleh beberapa aspek seperti, guru, siswa, media dan lingkungan. Apabila salah satu dari aspek tersebut bermasalah maka proses belajar mengajar dapat terganggu. Permasalahan dari guru diantaranya dalam menyajikan materi seringkali menggunakan metode konvensional yakni metode ceramah sehingga pembelajaran masih berpusat pada guru atau Teacher Center Learning (TCL), yang menyebabkan siswa menjadi jenuh dan bosan. Hal tersebut menyebabkan siswa cenderung kurang memiliki ketertarikan dalam kegiatan belajar mengajar, sehingga minat untuk mengikuti dan mempelajari lebih lanjut menjadi sangat kurang. Sementara itu permasalahan siswa terletak pada kecenderungan siswa yang kurang memiliki minat dalam proses belajar mengajar minat belajar yang rendah akan menghasilkan prestasi belajar yang rendah [3].

Berdasarkan hasil observasi

tanggal 1 April 2016 yang dilakukan peneliti di SMA Negeri 2 Karanganyar dengan mewawancarai salah seorang guru bidang studi kimia kelas $\mathrm{X}$ diketahui bahwa guru kimia di sekolah tersebut, semua masih mengajar menggunakan metode konvensional yaitu dengan metode ceramah, hal ini menunjukkan bahwa proses belajar mengajar masih terpusat pada gurusehingga belum sesuai kurikulum 2013. Hal tersebut mengakibatkan siswa mudah jenuh dan bosan dalam proses belajar mengajar. Dengan keadaan siswa yang jenuh dan bosan dengan metode mengajar guru yang kurang inovatif, menjadikan minat belajar siswa rendah. Rendahnya minat siswa dalam kegiatan pembelajaran akan memicu kurangnya ketertarikan siswa untuk mempelajari lebih lanjut mengenai materi yang sedang diajarkan. Sehingga rendahnya minat siswa dalam kegiatan pembelajaran dapat mengakibatkan nilai ulangan harian siswa kurang memuaskan.
Model pembelajaran yang baik dan sesuai akan berdampak pada keinginan serta ketertarikan siswa untuk menemukan dan membangun sendiri pemahaman mereka dalam materi pembelajaran yang tidak dapat di temukan pada metode konvensional. Menggunakan model pembelajaran yang bervariasi akan sangat membantu peserta didik dalam mencapai tujuan pembelajaran. Salah satu model pembelajaran yang dapat digunakan adalah model pembelajaran TAI (Team Assisted Individualization). Model pembelajaran ini menggunakan pembelajaran kelompok, siswa dibagi menjadi beberapa kelompok kecil, dalam kelompok tersebut terdapat salah satu siswa yang bertindak sebagai asisten. Langkah-langkah pembelajaran TAI (Team Assisted Individualization) adalah (1) Placement Test, yakni pemberian pre-test kepada siswa atau melihat rata-rata nilaiharian siswa agar guru mengetahui kelemahan siswa pada bidang tertentu. (2) Teams, yaitu pembentukan kelompok heterogen yang terdiri atas 4 sampai 5 siswa, (3) Student Creative, melaksanakan tugas dalam suatu kelompok dengan menciptakan situasi di mana keberhasilan individu ditentukan atau dipengaruhi oleh keberhasilan kelompoknya, (4) Team Study, yaitu tahapan tindakan belajar yang harus dilaksanakan oleh kelompok dan guru memberikan bantuan secara individual kepada siswa yang membutuhkannya, (5) Team Scores and Team Recognition, yaitu pemberian skor terhadap hasil kerja kelompok dan pemberian kriteria penghargaan terhadap kelompok yang berhasil secara cemerlang dan memberikan dorongan semangat kepada kelompok yang dipandang kurang berhasil dalam menyelesaikan tugas, (6) Teaching Group, yakni pemberian materi secara singkat dari guru menjelang pemberian tugas kelompok, (7) Facts Test, yaitu pelaksanaan tes-tes kecil berdasarkan fakta yang diperoleh siswa, dan (8) Whole-Class Units, yaitu pemberian materi kembali di akhir waktu pembelajaran oleh guru dengan strategi pemecahan masalah[4]. 
Dalam pembelajaran dengan model pembelajaran TAI (Team Assistedlndividualization), pembelajaran yang dilakukan secara berkelompok dan saling bertukar pikiran, akan meningkatkan minat siswa untuk terlibat dalam kegiatan pembelajaran. Dengan meningkatnya minat siswa dalam pembelajaran yang sesuai dengan karakteristik materi tentunya akan membantu dalam tercapainya tujuan pembelajaran yakni meningkatnya prestasi belajar siswa khususnya pada materi pokok stoikiometri. Penggunaan model pembelajaran TAl pada penelitian yang sebelumnya menunjukkan bahwa pembelajaran TAl lebih meningkatkan prestasi akademik siswa dibandingkan dengan metode konvensional [5]. Siswa mempunyai kesempatan untuk bekerja sama dalam kelompoknya, sehingga para siswa dapat bertukar wawasan dan pendapat yang digunakan untuk menyelesaikan masalah dalam proses diskusi.

Selain itu, dalam pembelajaran diperlukan suatu sarana untuk memudahkan guru dalam penyampaian materi kepada siswa melalui penggunaan media pembelajaran. Salah satu media pembelajaran yang dapat digunakan adalah buku saku. Buku saku merupakan salah satu media cetak yang pada penelitian sebelumnya menyatakan bahwa media cetak merupakan media tertua dalam pendidikan, yang berguna untuk tujuan informasi atau motivasi [6]. Buku saku berisi sekilas materi pelajaran dan soal-soal latihan yang dikemas dalam bentuk yang kecil, mudah dibawa dan tampilan yang menarik. Penerapan model pembelajaran TAI yang dilengkapi dengan buku saku diharapkan dapat meningkatkan ketertarikan siswa dalam memahami materi dan menyelesaikan soal-soal stoikiometri. Adanya ketertarikan tersebut siswa akan lebih antusias sehingga minat dan prestasi belajar menjadi meningkat. Hal ini didukung oleh penelitian sebelumnya yang menyatakan bahwa media pembelajaran berupa buletin Fisika dalam bentuk buku saku terbukti meningkatkan minat baca siswa yang kemudian berimbas pada peningkatan prestasi belajar siswa [7]

Dari uraian di atas dapat disimpulkan, rendahnya minat siswa dalam kegiatan pembelajaran dapat menurunkanprestasi belajar siswa, khususnya pembelajaran kimia pada materi pokok stoikiometri, yang disebabkan karena kurang sesuainya pemilihan dan penggunaan metode pembelajaran dengan karakteristik materi.

\section{METODE PENELITIAN}

Penelitian ini merupakan Penelitian Tindakan Kelas (PTK) yang terdiri dari dua siklus. Prosedur Penelitian Tindakan Kelas (PTK) yang digunakan dalam penelitian ini menggunakan model yang dikembangkan oleh Kemmis dan Mc Taggart yang terdiri dari tahap persiapan, perencanaan, pelaksanaan atau tindakan, observasi, dan refleksi [8]. Subjek penelitian adalah siswa kelas X IPA 6 SMA Negeri 2 Karanganyar yang berjumlah 29 siswa.

Sumber data adalah guru dan siswa. Teknik pengumpulan data adalah metode observasi, wawancara, angket, dan tes. Validitas data menggunakan teknik triangulasi. Triangulasi adalah teknik pemeriksaan keabsahan data yang memanfaatkan sesuatu yang lain di luar data itu untuk keperluan pengecekan atau sebagai pembanding terhadap data itu [9].

\section{HASIL DAN PEMBAHASAN}

Berdasarkan hasil wawancara dengan guru kimia yang mengampu kelas $\mathrm{X}$, observasi pada saat kegiatan pembelajaran dan tes minat prasiklus diperoleh fakta bahwa prestasi belajar dan minat siswa khususnya kelas X IPA 6 masih rendah. Oleh karena itu, perlu penanganan lebih lanjut dalam meningkatkan minat dan prestasi belajar siswa. Untuk mengatasi masalah tersebut diperlukan model pembelajaran yang tepat dan sesuai dengan materi pokok stoikiometri yaitu model pembelajaran TAI (Team Assisted Individualization) berbantuan Buku Saku. 


\section{Siklus I}

\section{a. Perencanaan Tindakan}

Pada tahap perencanaan tinda-kan meliputi penyusunan instrumen pembelajaran yang berupa persiapan silabus, penyusunan Rencana Pelak-sanaan Pembelajaran (RPP) dan pe-nyusunan instrumen penilaian aspek pengetahuan, angket penilaian diri siswa, lembar observasi sikap siswa, lembar observasi aspek keterampilan, dan lembar observasi minat siswa.

Penelitian ini menggunakan silabus yang didapatkan dari sekolah yang didasarkan pada kurikulum 2013. Sedangkan Rencana Pelaksaanaan Pembelajaran (RPP) yang digunakan ialah RPP yang disusun oleh peneliti bersama dengan guru pengampu kimia kelas $X$ yang disesuaikan dengan silabus dan model pembelajaran yang akan diterapkan.

\section{b. Pelaksanaan Tindakan}

Rencana pelaksanaan pembelajaran (RPP) yang telah disusun oleh peneliti dan guru diterapkan dalam kegiatan pembelajaran di kelas x IPA 6 SMA Negeri 2 karanganyar pada semester genap tahun pelajaran $2015 / 2016$. Pelaksanaan tindakan pada siklus 1 mulai dilaksanakan pada tanggal 14 April 2016. Model pembelajaran yang digunakan adalah TAl(Team Assisted individualization) berbantuan buku saku. Berdasarkan rencana pembelajaran yang telah disusun, pelaksanaan pembelajaran materi Stoikiometri pada siklus I dilakukan 5 kali pertemuan yaitu 8 jam pelajaran atau $8 \times 45$ menit untuk proses pembelajaran dan 2 jam pelajaran atau $2 \times 45$ menit untuk tes evaluasi aspek pengetahuan, angket sikap, dan angket minat.

Pertemuan ke 1 dan ke 2 siklus 1 , materi yang dibahas adalah mengenai konsep mol guru mengawali pembelajaran dengan apersepsi yang berupa pertanyaan dalam kehidupan sehari hari yang berkaitan dengan materi pelajaran yang akan diajarkan. Saat guru memberikan apersepsi, terlihat siswa berani menjawab pertanyaan hanya ketika bersama sama,ketika guru mempersilahkan siswa yang menjawab untuk angkat tangan tidak ada siswa yang berani menjawab. Setelah penjelasan singkat dari guru, siswa dalam kelompok diminta untuk berdiskusi tentang materi konsep mol yang telah diajarkan. Dalam kelompok ini terlihat bahwa asisten dalam kelompok bersemangat dalam membantu menjawab pertanyaan yang siswa lain tanyakan. Siswa terlihat lebih berani bertanya kepada teman sebaya atau asisten nya daripada kepada guru. Guru berkeliling untuk mengamati jalannya diskusi yang dilakukan siswa di dalam kelompoknya masing-masing dan memberikan penjelasan kepada siswa apabila terdapat permasalahan yang tidak bisa dijelaskan oleh asisten kelompok.

Tahap berikutnya, didalam buku saku sudah disediakan materi dan latihan soal yang dapat dikerjakan siswa sebagai latihan. Buku saku disusun dengan tampilan yang lebih atraktif sehigga dapat menarik minat siswa. Setelah kegiatan diskusi, guru meminta siswa untuk mengerjakan soal soal tersebut secara individu terlebih dahulu baru kemudian siswa diperbolehkan mengerjakan soal secara diskusi. Hal ini bertujuan untuk melatih siswa agar dapat menyeleseikan masalah secara individu dengan mengandalkan pemahaman diri sendiri, di dalam kelompok diharapkan siswa lebih berani untuk mengungkapkan pendapat berdasarkan pemahaman sendiri dan bekerja sama dalam menyeleseikan suatu masalah dalam kelompok dengan berbagai pemahaman individual siswa yang berbeda. Setelah selesai diskusi siswa diminta untuk maju ke depan kelas dan menjawab soal pertanyaan yang ada dalam diskusi, siswa terlihat antusias dengan tanpa ditunjuk untuk maju ke depan kelas. Apabila terdapat jawaban siswa yang belum benar guru menjelaskan kembali materi dan meminta siswa untuk membenarkan jawaban di depan kelas.

Kegiatan terakhir pada pembelajaran yang ada di setiap pertemuan siklus I adalah post test atau semacam pemberian soal kepada siswa yang berkaitan dengan materi stoikiometri yang telah diajarkan pada setiap 
pertemuan dan dikerjakan siswa secara individual. Melalui pemberian tes ini, dapat dijadikan tolak ukur mengenai pemahaman siswa terhadap materi yang telah diberikan. Kemudian tahapan terakhir dari siklus I adalah berupa ulangan siklus I yang dilaksanakan pada pertemuan ke-5, yang bertujuan untuk mengetahui kemampuan akhir siswa setelah menerima pembelajaran menggunakan model TAl(Team Assisted Individualization) dilengkapi dengan buku saku pada materi stoikiometri.

\section{c. Observasi Tindakan}

Kegiatan pembelajaran berlangsung selama 4 kali pertemuan, aspek sikap, keterampilan, minat belajar siswa dalam mengikuti pembelajaran diamati melalui lembar observasi di setiap pertemuan. Lembar observasi diisi oleh 4 orang observer. Dalam proses pembelajaran siswa menggunakan kartu identitas berupa kalung dengan kartu bertuliskan nomor absen yang diletakkan di dada dan punggung siswa supaya tampak dilihat dari depan maupun belakang, sehingga akan memudahkan observer untuk melakukan pengamatan dan mendapatkan data pengamatan sesuai kedaaan sebenarnya. Dalam hal ini siswa tidak mengetahui bahwa sikap, keterampilan, dan minat belajarnya sedang diamati. Observer dalam penelitian ini selalu sama dan observasi dilakukan dari awal penelitian hingga akhir penelitian.

Hasil penilaian analisis prestasi belajar siswa pada siklus I aspek pengetahuan dapat dilihat pada Tabel 1.

Tabel 1. Ketuntasan Prestasi Belajar Aspek Pengetahuan

\begin{tabular}{lcc}
\hline Kategori & $\begin{array}{c}\text { Jumlah } \\
\text { Siswa }\end{array}$ & $\begin{array}{c}\text { Ketuntasan } \\
(\%)\end{array}$ \\
\hline Tuntas & 12 & 41,38 \\
Tidak Tuntas & 27 & 58,62 \\
\hline
\end{tabular}

Berdasarkan hasil tes pengetahuan dapat diketahui bahwa prestasi belajar pada aspek penge-tahuan belum mencapai target yang ditentukan sebelumnya yaitu $70 \%$ siswa tuntas. Dari sepuluh indikator kom-petensi dan 20 indikator soal yang diukur pada siklus I terdapat 7 indikator soal mewakili 6 indikator kompetensi yang belum tercapai target.

Hasil penilaian sikap siswa dapat dilihat pada Gambar 1.

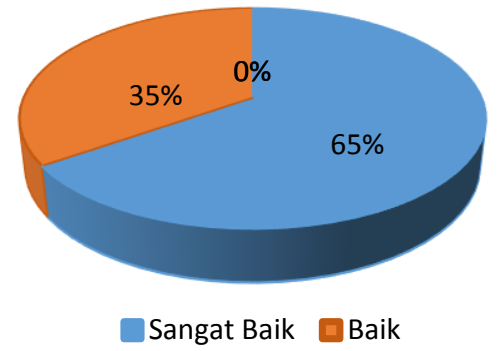

Gambar 1. Hasil Ketercapaian Aspek SikapSiswa Siklus I

Pada siklus I ketuntasan siswa aspek sikap mencapai $100 \%$ dan semua aspek atau indikator telah memenuhi target yang ditentukan pada siklus I, meskipun pada indikator kejujuran dan kerjasama memperoleh ketuntasan $82 \%$ dan $90 \%$, sehingga penelitian aspek sikap tidak dilanjutkan pada siklus II.

Hasil yang diperoleh pada prestasi belajar aspek keterampilan tercantum dalam Tabel 2.

Tabel 2. Ketercapaian Aspek Keterampilan Siklus I

\begin{tabular}{lcc}
\hline Aspek Keterampilan & $\begin{array}{c}\text { Target } \\
(\%)\end{array}$ & $\begin{array}{c}\text { Keterca- } \\
\text { paian } \\
(\%)\end{array}$ \\
\hline Mengamati & 70 & 93,1 \\
Menanya & 70 & 96,5 \\
Mengumpulkan & 70 & 100,0 \\
Informasi & 70 & 100,0 \\
Mengasosiasi & 70 & 100,0 \\
\hline
\end{tabular}

Berdasarkan analisis aspek keterampilan siklus I, hal tersebut menunjukkan bahwa siswa sudah terampil dalam melaksanakan pembelajaran dengan keterampilan saintifik.

Hasil yang diperoleh pada minat siswa dapat dilihat pada Gambar 2. 


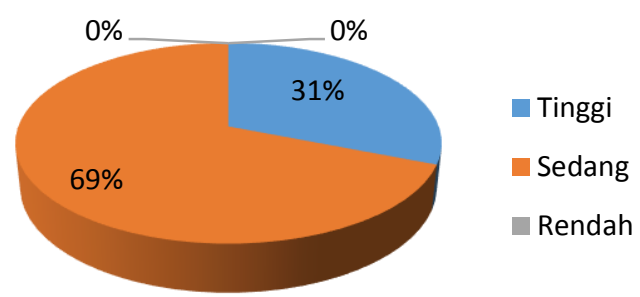

Gambar 2. Hasil Ketercapaian Minat Siswa Siklus I

Pada siklus I ketercapaian minat sebesar $100 \%$, hasil tersebut sudah memenuhi target ketercapaian yaitu $70 \%$, sehingga tidak perlu dilanjutkan ke siklus II.

\section{d. Refleksi Tindakan}

$\begin{array}{rrr}\text { Berdasarkan observasi } & \text { tindakan } \\ \text { dapat diketahui } & \text { bahwa aspek }\end{array}$ pengetahuan belum mencapai target. Oleh karena itu, perlu adanya tindakan pada siklus II sehingga ketercapaian seluruh indikator kinerja dapat tuntas seluruhnya dan kekurangan yang ada pada siklus I diperbaiki pada siklus II. Perbaikan yang direncanakan untuk pembelajaran siklus II yaitu meyusun Rencana Pelaksanaan Pembelajaran (RPP) yang lebih difokuskan pada indikator kompetensi yang belum dikuasai oleh siswa.

\section{Siklus II}

\section{a. Perencanaan Tindakan}

Berdasarkan hasil refleksi pada siklus 1 maka dilakukan perencanaan pelaksanaan tindakan pada siklus II. Peneliti dan guru bersama sama melakukan perencanaan pada siklus II. Pada Siklus II materi difokuskan pada indikator soal yang belum tuntas pada siklus I.

Tindakan pada siklus II difokuskan untuk menyempurnakan dan memperbaiki kendala-kendala yang ada pada siklus I. Pada siklus II, peneliti dan guru tidak lagi melakukan penilaian sikap, keterampilan, dan minat belajar karena ketiga aspek tersebut sudah mencapai target yang telah ditetapkan yaitu $70 \%$. Aspek sikap dan keterampilan siswa sudah tergolong baik dan minat belajar siswa juga tergolong tinggi. Penilaian aspek pegetahuan pada siklus II dengan tes objektif menggunakan soal yang berbeda namun dengan indikator soal yang belum tuntas pada siklus I yaitu sebanyak 7 soal. Instrumen penilaian pegetahuan siklus II sebelum digunakan terlebih dahulu divalidasi, ditryoutkan, dan dianalisis untuk mengetahui kelayakan instrumen sebagai alat evaluasi.

\section{b. Pelaksanaan Tindakan}

Pelaksanaan pembelajaran pada siklus II terdiri dari dua kali pertemuan, satu kali pertemuan untuk memberikan materi dan satu kali pertemuan untuk evaluasi siklus II. Sama seperti pada siklus I, setiap pertemuan berlangsung selama dua jam pelajaran dimana satu jam pelajaran adalah 45 menit. Pertemuan pertama diawali guru dengan mengulang materi stoikiometri pada indikator kompetensi yang belum tuntas pada siklus I. Guru menerapkan model pembelajaran TAI (Team Assisted Individualization) berbantuan buku saku. Pada awal pembelajaran, guru memberikan apersepsi untuk mengingatkan kembali materi yang telah dipelajari pada siklus I. Siswa dalam kelompok yang sama seperti pada siklus I, diminta untuk bertanya tentang hal apa saja dalam indikator kompetensi tersebut yang mereka rasa belum jelas. Guru memberikan pertanyaan umpan balik untuk mengajak siswa berpartisipasi aktif dalam pembelajaran. Dalam proses pembelajaran terlihat adanya peningkatan intensitas komunikasi dua arah antara guru dan siswa. Selanjutnya guru mengajak untuk membahas kembali beberapa soal yang dirasa sulit oleh siswa pada saat tes aspek pengetahuan siklus I. Dalam menerangkan guru lebih banyak menggunakan contoh-contoh dalam aplikasi soal. Kemudian siswa diminta untuk mencatat dan menambahkan konsep dan teori apa saja yang perlu diberi penekanan pada buku saku yang mereka miliki. Guru juga menunjuk salah satu siswa yang selama siklus I berperan lebih pasif untuk maju ke depan mengerjakan latihan soal dan membimbing siswa agar benar dalam menjawab. Melalui cara seperti itu dapat menumbuhkan rasa keberanian dan percaya diri pada siswa bahwa 
sebenarnya mereka mampu menyelesaikan soal-soal yang diberikan. Pada pertemuan pertama, dapat dilihat bahwa siswa yang pada siklus I pasif menjadi lebih aktif dalam mengikuti pembelajaran dan mereka menjadi lebih paham dan mengingat materi yang diberikan. Guru menutup pertemuan pertama dengan memberikan soal post tes kepada siswa secara individu yang terdiri dari 2 soal dengan alokasi waktu 7 menit. Post test untuk mengetahui sejauh mana pemahaman terhadap materi, dan hasil yang diperoleh dari postest diketahui bahwa hampir seluruh siswa sudah menjawab dengan benar.

Evaluasi aspek pengetahuan pada siklus II ini dilaksanakan pada pertemuan kedua. Tes aspek pengetahuanterdiri dari 7 soal objektif dengan alokasi waktu 45 menit. Soal tes pengetahuan yang digunakan hanya memuat indikator kompetensi yang belum tercapai, serta indikator soal yang belum tercapai atau ketercapaian rendah.

\section{c. Observasi Tindakan}

Pembelajaran pada siklus II menurut hasil observasi siswa terlihat lebih antusiasdalam mengikuti pelajaran dibandingkan ketika pembelajaran di siklus I. Siswa lebih banyak mengemukakan gagasandan aktif dalam proses pembelajaran. Di siklus II terlihat siswa yang sudah paham dengan materi stoikiometri membantu temannya yang belum paham dalam satu kelompok. Guru dalam proses pembelajaran di siklus II ini berperan sebagai fasilitator dalam kegiatan diskusi ataupun presentasi serta memberikan penekanan materi yang penting dan harus dipahami siswa.

Analisis hasil prestasi belajar siswa aspek pengetahuan siklus II dapat dilihat pada Tabel 3.

Tabel 3. Hasil Ketercapaian Aspek Kognitif Siklus II

\begin{tabular}{ccc}
\hline Kriteria & $\begin{array}{c}\text { Jumlah } \\
\text { Siswa }\end{array}$ & Ketercapaian (\%) \\
& 21 & 72,41 \\
Tuntas & 21 & 27,58 \\
\hline
\end{tabular}

Hasil ini sudah memenuhi target ketuntasan dan semua indikator kompetensi, serta indikator soal telah mencapai target penelitian.

\section{d. Refleksi Tindakan}

Berdasarkan data yang diperoleh pada siklus II, terlihat semua aspek meliputi aspek pengetahuanmengalami peningkatan capaian dan sudah melampaui target sehingga penelitian di akhiri pada siklus II.

\section{Perbandingan Tindakan Antar Siklus}

Peningkatan yang terjadi selama proses pembelajaran ditunjukkan dengan perbandingan hasil antar siklus I dengan siklus II yang disajikan pada Gambar 3.

Hasil siklus I dan siklus II menunjukkan bahwa semua aspek telah memenuhi target yang direncanakan dan penelitian selesai pada siklus II. Dalam penelitian tindakan kelas, penelitian dapat dinyatakan berhasil apabila semua aspek yang diukur atau indikator kinerja telah mencapai target yang telah ditetapkan. Penelitian ini dapat disimpulkan berhasil karenaminat dan prestasi belajar yang meliputi aspek pengetahuan, aspek sikap dan keterampilan siswa yang diukur telah memenuhi target yang ditetapkan.Salah satu faktor yang menyebabkan meningkatnya minat belajar menurut peneliti adalah model dan media pembelajaran yang digunakan. Penggunaan model pembelajaran TAl sesuai untuk materi stoikiometrikarena dalam pembelajaran TAl terdapat seorang siswa yang yangberperan sebagai asisten yang bertugas membantu secara individual siswa lain yang kurang mampu dalam suatu kelompok. Hal ini didukung oleh penelitian yang menyimpulkan bahwa penggunaan pembelajaran TAl menghasilkan nilai akademik yang lebih tinggi dibanding dengan metode pengajaran konvensional [5].

Buku saku merupakan salah satu media cetak yang pada penelitian sebelumnya menyatakan bahwa media cetak merupakan media tertua dalam pendidikan, yang berguna untuk tujuan informasi atau motivasi [6]. Buku saku 
yang berisi sekilasmateri pelajaran secara keseluruhan memungkinkan siswa mencari materi pada pertemuan sebelumnya dan siswa yang masih kurang memahami materi dapat lebih paham dengan adanya penjelasan dari asisten. Hal ini juga dikarenakan media buku saku merupakan buku yang berukuran kecil yang mana berisi informasi yang dapat disimpan di saku sehingga mudah dibawa kemana-mana sehingga dengan adanya media buku saku ini siswa mudah memahami konsep-konsep pada materi stoikiometri yang disajikan oleh guru dan siswa menjadi lebih termotivasi dan meningkatkan minat baca untuk belajar sehingga tujuan pembelajaran dapat tercapai.Hal ini didukung oleh penelitian sebelumnya yang menyatakan bahwa media pembelajaran berupa buletin Fisika dalam bentuk buku saku terbukti meningkatkan minat baca siswa yang kemudian berimbas pada peningkatan prestasi belajar siswa [7].

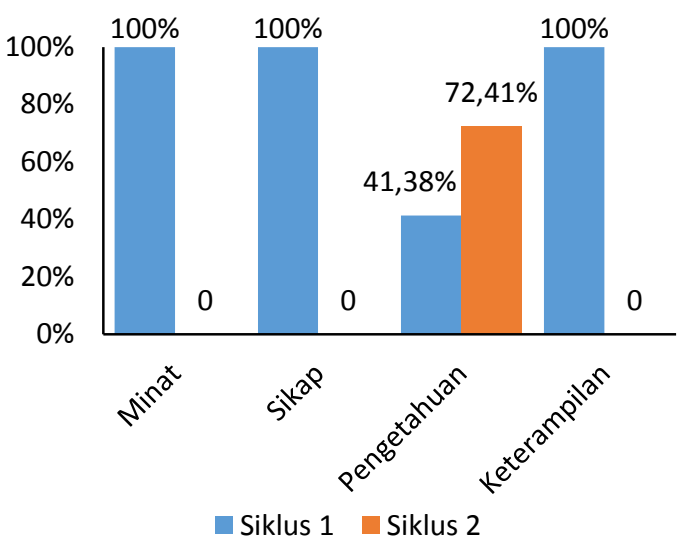

Gambar 3. Perbandingan Hasil Antar Siklus

Pada Gambar 3 menunjukkan terjadinya peningkatan capaian dari siklus I ke siklus II untuk semua aspek yang meliputi aspek pengetahuan, sikap, keterampilan dan sikap ilmiah.

Hasil penelitian ini menunjukkan bahwa, penerapan Model pembelajaran TAI (Team Assistedlndividualization) berbantuan Buku Saku dapat Meningkatkan Minat dan Prestasi belajar Siswa pada Materi Pokok Stoikiometri Kelas $X$ IPA 6 di SMAN 2 Karanganyar.

\section{KESIMPULAN}

Berdasarkan hasil penelitian yang telah dilaksanakan, maka dapat diperoleh kesimpulan bahwa penerapan Model pembelajaran TAI (Team Assisted Individualization) berbantuan Buku Saku dapat Meningkatkan Minat dan Prestasi belajar Siswa pada Materi Pokok Stoikiometri Kelas X IPA 6 di SMANegeri 2 Karanganyar. Ketercapaian minat siswa pada siklus I sebesar 100\%. aspek pengetahuan pada siklus I diperoleh ketuntasan belajar sebesar $41,38 \%$ dan pada siklus II meningkat menjadi $72,41 \%$. Aspek sikap pada siklus I ketercapaiannya sebesar $100 \%$. Sedangkan untuk aspek keterampilan ketercapaiannya sebesar $100 \%$.

\section{UCAPAN TERIMA KASIH}

Dalam kesempatan ini peneliti mengucapkan terima kasih kepada Dra. $\mathrm{Hj}$. Suliyastuti selaku Kepala SMA Negeri 2 Karanganyar yang telah memberikan izin untuk mengadakan penelitian di SMA Negeri 2 Karanganyar. Kepada Bapak Alimin Sutanto, S.Pd., selaku guru mata pelajaran kimia kelas X IPA SMA Negeri 2 Karanganyar yang telah mengizinkan peneliti untuk menggunakan kelasnya dalam penelitian ini.

\section{DAFTAR RUJUKAN}

[1] Kementerian Pendidikan dan Kebudayaan. (2013). Peraturan Menteri Pendidikan dan Kebudayaan Republik Indonesia Nomor 69 Tahun 2013 Tentang Kerangka Dasar dan Struktur Kurikulum Sekolah Menengah Atas/Madrasah Aliyah. Jakarta: Kementerian Pendidikan dan Kebudayaan.

[2] Chang, Raymond. (2005). Kimia Dasar: Konsep-konsep Inti Jilid I. Jakarta: Erlangga.

[3] Djamarah, S.B. (2011). Psikologi Belajar. Jakarta: Rineka Cipta. 
[4] Slavin, R.E. (2008). Cooperative Learning, Teori, Riset dan Praktik. Terjemahan oleh Narulita Yusron. Bandung: Nusa Media.

[5] Nneji, L. (2011). Impact of Framing and Team Assisted Individualization Instructional Stategies Student' Achievment in Basic Science in The North Central Zone of Nigeria. Nigerian Educational Reseach Journal, 23 (4), 1-8.

[6] Onasanya, S.A. (2004). Selection and Utilization of Instructional Media for Effective Practice Teaching. Institute Journal of Studies in Education. 2 (1), 127-133.
[7] Setyono,Y.A. (2012). Pengembangan Media Pembelajaran Fisika Berupa Buletin Dalam Bentuk Buku Saku Untuk Pembelajaran Fisika Kelas VIII Materi Gaya Ditinjau Dari Minat Baca Siswa . Surakarta :UNS.

[8] Arikunto, S. (2008). Penelitian Tindakan Kelas. Jakarta: Bumi Aksara.

[9] Sugiyono. (2010). Metode Penelitian Pendidikan Pendekatan Kuantitatif, Kualitatif, dan $R$ \& $D$. Bandung: Alfabeta. 